\title{
PENGARUH OPERATING CAPACITY, SALES GROWTH DAN ARUS KAS OPERASI TERHADAP FINANCIAL DISTRESS
}

(Studi Empiris pada Perusahaan Sektor Pertanian yang Terdaftar di Bursa Efek Indonesia Periode 2013-2017)

\author{
Annisa Livia Ramadhani \\ Annisa.livia@yahoo.com \\ Fakultas Ekonomi dan Bisnis, Universitas Telkom \\ Khairunnisa.,SE M.M \\ Khairunnisa@telkomuniversity.ac.id \\ Fakultas Ekonomi dan Bisnis, Universitas Telkom
}

\begin{abstract}
This study aims to determine how the influence of operating capacity, sales growth and operating cash flows on financial distress. The population in this study israll agricultural sector companies listed on the Indonesia Stock Exchange (IDX) in 2013-2017. The sampling technique in this study used purposive sampling which produced 8 samples in a period of 5 years, namely as many as 40 units of data samples. The analytical method used is logistic regression analysis which is processed. using SPSS Version 25. Based on the results of this study, it was found that simultaneous operating capacity, sales growth and operating cash flows influence the occurrence of financial distress. Then partially, operating capacity and sales growth have no effect on the occurrence of financial distress, while operating cash flows have a positive and significant effect on the occurrence of financial distress.
\end{abstract}

Keyword: Financial Distress, Operating capacity, Sales growth, Operation cash flow. 


\section{PENDAHULUAN}

Menurut Hanafi dan Halim (2016:49) laporan keuangan adalah sumber informasi yang penting dibandingkan dengan informasi lainnya. Laporan keuangan memiliki peran yang penting bagi kelangsungan suatu perusahaan, karena di dalam laporan keuangan kita dapat mengetahui kondisi perusahaan apakah perusahaan tersebut sehat atau sedang mengalami masa kritis.

Analisis laporan keuangan digunakan untuk dapat mengetahui total jumlah penghasilan yang diterima dan jumlah beban yang telah dikeluarkan selama periode tertentu sehingga dapat mengetahui hasil usaha yang sudah diperoleh (Kasmir 2017:66). Analisis laporan keuangan dilakukan untuk dapat mengetahui langkah yang harus dilakukan kedepannya untuk mencegah terjadinya kebangkarutan ataupun financial distress.

Financial distress adalah masalah atau situasi yang harus dihindari oleh perusahaan. Menurut Platt dan Plat dalam Widhiari dan Merkusiwati (2015) financial distress adalah proses penurunan sebelum terjadinya kebangkrutan. Terdapat beberapa model untuk mendeteksi terjadinya financial distress, salah satunya adalah Altman ZScore.

Model Altman Z-Score dibentuk oleh Dr. Edward I. Altman pada tahun 1968 di New York University dengan menggunakan metode Multiple Discriminant Analysis (MDA). Dalam metode MDA dibutuhkan lebih dari satu rasio keuangan yang berhubungan dengan kebangkrutan untuk menjadi suatu model yang komprehensif (Gustiyana, 2018).

Laba menjadi salah satu tolak ukur kesehatan perusahaan. Laba pada umumnya dapat dipandang sebagai suatu dasar bagi pengambilan keputusan investasi. Sehingga dapat disimpulkan bahwa laba memiliki peran yang sangat penting bagi kelangsungan perusahaan, apabila laba perusahaan tersebut mengalami penurunan akan berdampak buruk terhadap perusahaan itu sendiri. Menurut Platt dan Platt dalam Verani, Elyzabet dan Derry (2017) mengukur financial distress berdasarkan delapan kondisi dan salah satunya merupakan laba operasi negatif dalam beberapa tahun terakhir.

Sektor pertanian secara keseluruhan memiliki laba yang negatif di tahun 2017 akhir, hal tersebut terjadi dipicu oleh kebijakan Kementan yang menentukan kebijakan untuk impor yang kurang tepat. Jika hal tersebut terjadi terusmenerus tanpa dapat diatasi akan mengakibatkan terjadinya financial distress.

Banyak faktor yang dapat mempengaruhi terjadinya financial distress salah satu nya adalah operating capacity, sales growth dan arus kas operasi.

Operating capacity menggambarkan kemampuan perusahaan dalam menggunakan sumber daya atau aset yang dimilikinya untuk pengelolaan perusahaan (Meiranto, 2014). Proksi yang digunakan dalam penelitian ini adalah Total Asset Turnover (TATO), yaitu dengan membandingkan nilai ratarata total penjualan dengan rata-rata total aset yang dimiliki oleh perusahaan. Jika perhitungan operating capacity memiliki hasil yang rendah, dapat mengindikasikan bahwa perusahaan tidak efisien dalam menggunakan asetnya dan apabila tidak dapat diatasi, hal tersebut dapat mengakibatkan terjadinya financial distress. Hal tersebut sejalan dengan penelitian yang dilakukan oleh Widhiari dan Merkusiwati (2015).

Pertumbuhan penjualan (sales growth) adalah perubahan penjualan 
yang mengalami peningkatan ataupun penurunan dan dapat dilihat dalam laporan laba rugi perusahaan (Maryanti, 2016). Perusahaan dengan pertumbuhan penjualan (sales growth) yang bersifat positif memberikan tanda bahwa kondisi perusahaan tersebut baik, sedangkan sebaliknya pertumbuhan penjualan yang bersifat negatif secara terus menerus dapat mengindikasikan terjadinya financial distress. Hal tersebut sejalan dengan penelitian yang telah dilakukan oleh Wiwin dan Dani (2017).

Arus kas operasi merupakan bagian dari laporan keuangan yang dapat memberikan informasi mengenai penerimaan dan pengeluaran kas dalam suatu periode dengan membagi menjadi dua bagian yaitu operasi pembiayaan dan investasi (Harahap, 2010:257). Jika arus kas operasi bernilai kecil, investor tidak akan memiliki keyakinan untuk berinvestasi pada perusahaan tersebut, apabila hal ini berlangsung secara terus menerus dan tidak dapat diatasi maka akan mengakibatkan terjadinya financial distress. Hal ini sejalan dengan penelitian yang sudah dilakukan oleh Amarilla et al (2017).

\section{KERANGKA TEORITIS DAN HIPOTESIS}

\section{Financial Distress}

Menurut Altman dalam Sri Yati (2017) mendefinisikan financial distress menggunakan angka - angka yang ada di laporan keuangan dan mempresentasikannya dalam suatu proksi atau model yaitu Altman Z-Score yang dapat menjadi acuan apakah perusahaan berpotensi untuk bangkrut atau tidak. Dalam penelitian ini proksi atau model yang digunakan untuk menilai financial distress adalah model Altman Z-Score Modifikasi (1995) :

$$
Z=6,56 \times 1+3,26 \times 2+6,72 X 3+1,04 X 4
$$

Keterangan :

$\mathrm{X} 1$ = Worngkin capital/Total Asset

$\mathrm{X} 2=$ Retained Earnings/Total Asset

$\mathrm{X} 3=$ EBIT/Total Asset

$\mathrm{X} 4=$ Book value of equity/Book Value of Liabilities

\section{Operating Capacity}

Menurut Fahmi (2014:77) operating capacity adalah rasio yang menggambarkan efisiensi perusahaan dalam menggunakan sumber daya yang dimilikinya untuk dapat membiayai kegiatan operasional perusahaan. Proksi yang digunakan dalam penelitian ini adalah Total Asset Turnover (TATO) digunakan untuk mengukur tingkat efisiensi dan efektifitas perusahaan dalam menggunakan aset yang dimilikinya untuk menghasilkan penjualan (Hery, 2015:179).

$$
\frac{\text { Penjualan }}{\text { Rata - rata Total Aset }}
$$

\section{Sales Growth}

Pertumbuhan penjualan (sales growth) menggambarkan keberhasilan investasi yang telah dilakukan oleh perusahaan pada periode sebelumnya dan dapat digunakan sebagai prediksi untuk kelangsungan perusahaan di periode berikutnya (Widhiari dan Merkusiwati, 2015). Pertumbuhan penjualan (Kasmir 2017:107) :

Penjualan tahun ini - penjualan tahun sebelumnya penjualan tahun sebelumnya

\section{Arus Kas Operasi}

Menurut Hary (2015:89) arus kas yang paling utama adalah arus kas operasi. Proksi yang digunakan untuk menghitung arus kas operasi dalam penelitian ini adalah rasio arus kas operasi terhadap utang lancar :

Arus Kas Operasi

Kewajiban lancar 


\section{HIPOTESIS}

\section{Pengaruh Operating Capacity \\ Terhadap Financial Distress \\ Operating capacity merupakan rasio} yang digunakan untuk mengukur efisiensi penggunaan sumber daya atau aset yang dimiliki perusahaan untuk menghasilkan penjualan. Proksi yang digunakan adalah total asset turnover (TATO). Apabila TATO menghasilkan nilai yang tinggi maka perputaran aset lebih cepat sehingga menghasilkan laba dan pemakaian keseluruhan aset dalam menghasilkan penjualan semakin optimal. Dengan nilai TATO yang tinggi juga dapat berarti jumlah aset yang sama dapat memperbesar volume penjualan sehingga semakin minim kemungkinan perusahaan untuk mengalami financial distress, begitu juga sebaliknya (Widhiari dan Merkusiwati, 2015).

H1: Operating capacity berpengaruh negatif signifikan terhadap financial distress.

\section{Pengaruh sales growth terhadap financial distress \\ Pertumbuhan penjualan dapat} digunakan sebagai indikator financial distress, karena semakin tinggi nilai tingkat pertumbuhan penjualan maka menggambarkan bahwa perusahaan tersebut berhasil menjalankan rencana dan aktivitasnya. Hal ini berarti semakin besar laba yang dihasilkan yang berdampak pada bertambahnya arus kas perusahaan, sehingga semakin kecil kemungkinan perusahaan mengalami financial distress, begitu juga sebaliknya apabila pertumbuhan penjualan mengalami penurunan yang tidak dapat diatasi oleh perusahan hal tersebut dapat mengakibatkan terjadinya financial distress (Wiwin dan Dani, 2017).

H2: Sales Growth berpengaruh negatif signifikan terhadap financial distress
Pengaruh arus kas operasi terhadap financial distress

Arus kas operasi merupakan indikator yang penting yang dilihat oleh pihak kreditor maupun investor untuk mengetahui kondisi perusahaan. Perusahaan yang memiliki arus kas operasi yang tinggi berarti memiliki sumber dana untuk melaksanakan aktivitas operasinya seperti untuk melunasi pinjaman, memelihara kemampuan operasi perusahaan, membayar deviden. Jika arus kas operasi yang dihasilkan perusahaan mengalami kenaikan, maka semakin kecil kemungkinan perusahaan mengalami financial distress, begitu juga sebaliknya apabila arus kas operasi perusahaan mengalami penurunan secara terus menerus tanpa dapat diatasi, perusahaan dapat mengalami financial distress (Amarilla et al, 2017).

H3: Arus kas operasi berpengaruh negatif signifikan terhadap financial distress

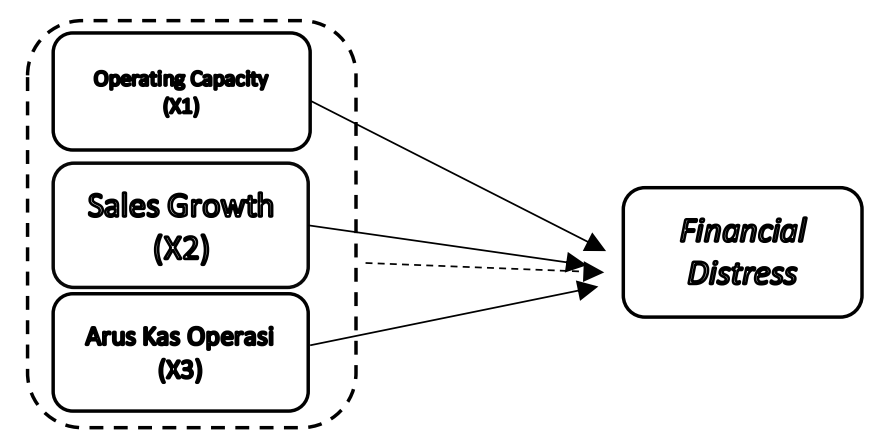

Gambar 1. Kerangka Pemikiran

\section{METODELOGI}

Jenis Penelitian

Jenis penelitian ini merupakan penelitian kuantitatif yaitu penelitian yang menghasilkan penemuanpenemuan yang dapat diperoleh dengan menggunakan prosedur-prosedur 
statistik atau cara-cara lain dari kuantifikasi atau pengukuran (Sujarweni 2015:12.

\section{Jenis dan Sumber Data}

Data yang digunakan dalam penelitian ini adalah data sekunder, berupa laporan keuangan auditan dan annual report sektor pertanian yang listed di Bursa Efek Indonesia (BEI) tahun 2012-2017.

\section{Populasi dan Sampel Penelitian}

Populasi yang digunakan dalam penelitian ini adalah seluruh perusahaan sektor pertanian yang terdaftar di Bursa Efek Indonesia (BEI) periode 20132017. Teknik pengambilan sampel pada penelitian ini menggunakan purposive sampling. Kriteria yang digunakan dalam penelitian ini adalah :

1. Perusahaan sektor pertanian yang secara konsisten terdaftar Bursa Efek Indonesia pada tahun 20122017

2. Perusahaan yang tidak mengalami laba atau Earning Before Tax and Interest (EBIT) negatif selama lebih dari 2 tahun

3. Perusahaan sektor pertanian yang menyediakan informasi yang dibutuhkan dari variabel variabel penelitian pada tahun 2012-2017

Berdasarkan kriteria tersebut maka jumlah sampel yang digunakan dalam penelitian ada 8 perusahaan dari 19 perusahaan yang memenuhi kriteria yang sudah ditentukan.

\section{Teknik Analisis Data}

Teknik analisis data dalam penelitian ini adalah analisis kuantitatif menggunakan teknik perhitungan statistik deskriptif. Metode analisis yang digunakan dalam penelitian ini adalah analisis regresi logistik.

\section{Model Regresi Logistik}

Model regresi yang digunakan dalam penelitian ini adalah :

$\operatorname{Ln} \frac{\text { FD }}{(1-F D)}=\alpha+\beta 1$ Tato $+\beta 2$ Sales $+\beta 3$ Arus kas $+\varepsilon$

Keterangan :

$\operatorname{Ln} \frac{\mathrm{FD}}{(1-F D)}$ : Probabilitas perusahaan mengalami financial distress

$\boldsymbol{\alpha}$ : Konstanta

$\boldsymbol{\beta 1}$ :Koefisien regresi dari Operating Capacity

及2:Koefisien regresi dari Sales Growth 及3:Koefisien rgresi dari Arus kas operasi $\boldsymbol{\varepsilon}$ : Kesalahan / error.

\section{HASIL ANALISIS DAN PEMBAHASAN}

\section{Menilai Kelayakan Model Regresi}

Tabel 1 Hosmer and Lemeshow

\begin{tabular}{|l|l|l|}
\hline Chi-square & df & Sig. \\
\hline 12.957 & 8 &, 113 \\
\hline
\end{tabular}

Berdasarkan tabel diatas diketahui bahwa nilai chi-square sebesar 12.957 dengan nilai sig. 0,113 atau 11,3\%. Hasil ini menunjukkan bahwa nilai sig lebih besar dari nilai $\alpha(0,05)$. Artinya hipotesis nol diterima yang berarti bahwa model mampu memprediksi nilai observasinya atau dapat dikatakan model cocok dengan observasinya.

Menilai Model Fit (-2LogL)

Tabel 2 Model Fit (-2LogL)

\begin{tabular}{|l|l|}
\hline $\begin{array}{l}-2 \operatorname{LogL} \text { Block } \\
\text { Number }=0\end{array}$ & Nilai $=52.925$ \\
\hline $\begin{array}{l}-2 \operatorname{LogL} \quad \text { Block } \\
\text { Number }=1\end{array}$ & Nilai $=38.678$ \\
\hline
\end{tabular}

Sumber: Output SPSS 25

Berdasarkan tabel 2 nilai $-2 \log \mathrm{L}$ awal $(-2 \log \mathrm{L}$ Block Number $=0$ ) dimana model hanya memasukkan 
konstanta, menunjukkan nilai sebesar 52.925. sedangkan, nilai -2LogL langkah berikutnya (-2LofL Block Number $=1)$, dimana variabel dimasukkan kostanta dan variabel bebas atau variabel independen $(\mathrm{X})$, menunjukkan nilai yang lebih kecil yaitu 36,678. Perbandingan antara kedua nilai tersebut mengalami penurunan besar sebesar 16,247. Sehingga dapat disimpulkan model fit dengan data dan terbukti bahwa variabel operating capacity, sales growth dan arus ka soperasi dapat memperbaiki model fit.

\section{Koefisien Determinasi (R2)}

Tabel 3 Koefisien Determinasi

\begin{tabular}{|l|l|l|}
\hline $\begin{array}{l}-2 \quad \text { Log } \\
\text { Likelihood }\end{array}$ & $\begin{array}{l}\text { Cox \& Snell } \\
\text { R Square }\end{array}$ & $\begin{array}{l}\text { Negelkerke } \\
\text { R Square }\end{array}$ \\
\hline 38,678 &, 300 &, 408 \\
\hline
\end{tabular}

Sumber: Output SPSS 25

Berdasarkan pengolahan data menggunakan analisis regresi logistik, diperoleh nilai Negelkerke R Square sebesar 0,408 yang berarti kombinasi antara operating capacity, sales growth dan arus kas operasi dari financial distress sebesar $40,8 \%$ dan sisanya dijelaskan oleh faktor-faktor yang tidak diteliti dalam penelitian ini.

\section{Hasil Pengujian Simultan}

Tabel 4 Omnimbus test of Model Coefficients

\begin{tabular}{|l|l|l|l|}
\hline & $\begin{array}{l}\text { Chi- } \\
\text { Square }\end{array}$ & df & Sig \\
\hline Step & 14.247 & 3 &, 003 \\
\hline Block & 14.247 & 3 &, 003 \\
\hline Model & 14.247 & 3 &, 003 \\
\hline
\end{tabular}

Sumber: Output SPSS 25

Berdasarkan tabel 4 menunjukkan bahwa nilai Chi-Square sebesar 14.427 dengan degree of freedom (df) yaitu 3. Tingkat signifikansi yang dihasilkan adalah sebesar 0,003 atau 3\%. Sehingga dapat dikatakan bahwa nilai signifikansi
F kurang dari 0,05. Sehingga dengan demikian hipotesis independen $\mathrm{H} 0$ ditolak dan $\mathrm{Ha}$ diterima, yang berarti secara simultan variabel independen (x) Operating capacity, Sales growth dan Arus Kas Operasi memiliki pengaruh terhadap variabel dependen (Y) yaitu financial distress.

\section{Hasil Pengujian Secara Parsial}

95\% C.I.for EXP(B)

\begin{tabular}{ccc|c|c|c|c|c|c|c} 
& & B & S.E. & Wald & df & Sig. & $\operatorname{Exp}(\mathrm{B})$ & Lower & Upper \\
\hline \multirow{2}{*}{$\begin{array}{c}\text { Step } \\
1^{\mathrm{a}}\end{array}$} & TATO & .028 & 1.085 & .001 & 1 & .979 & 1.028 & .123 & 8.615 \\
\cline { 2 - 11 } & SG & -2.289 & 2.400 & .910 & 1 & .340 & .101 & .001 & 11.181 \\
\cline { 2 - 10 } & AK0 & 3.934 & 1.558 & 6.377 & 1 & .012 & 51.124 & 2.412 & 1083.380 \\
\hline & Constant &. .827 & .957 & .748 & 1 & .387 & .437 & & \\
\hline
\end{tabular}

Sumber: Output SPSS 25

1. Nilai Sig. variabel operating capacity yang diproksikan dengan Total Asset Turnover sebesar 0,979 lebih besar dari tingkat signifikansi $\alpha 0,05$. Maka dapat disimpulkan bahwa $\mathrm{H} 0$ diterima dan Ha ditolak sehingga secara parsial operating capacity tidak berpengaruh signifikan terhadap terjadinya financial distress.

2. Nilai Sig, variabel sales growth sebesar 0,340 yang lebih besar dari tingkat signifikansi $\alpha 0,05$. Maka dapat disimpulkan bahwa H0 diterima dan $\mathrm{Ha}$ ditolak sehingga secara parsial sales growth tidak berpengaruh signifikan terhadap terjadinya financial distress.

3. Nilai Sig. variabel arus kas operasi yang diproksikan dengan rasio arus kas terhadap utang lancar sebesar 0,012 yang lebih kecil dari tingkat signifikansi $\alpha$ 0,05 yang berarti terdapat pengaruh variabel arus kas operasi terhadap financial 
distress. Koefisien regresi sebesar 3,934 menunjukkan arah yang berlawanan dengan hipotesis penelitian, maka dapat disimpulkan bahwa Ha diterima dan H0 ditolak sehingga secara parsial arus kas operasi memiliki pengaruh signifikan terhadap terjadinya financial distress, namun dengan arah positif.

\section{Pengaruh operating capacity terhadap financial distress}

Berdasarkan pengujian secara parsial diketahui bahwa vatianel operating capacity yang diproksikan dengan rasio Total Asset Turnover (TATO) memiliki nilai koefisien sebesar 0,028 dengan nilai signifikansi sebesar 0,979 lebih besar dari tingkat signifikansi yang disyaratkan yaitu $\alpha 0,05$ (5\%). Sehingga dapat disimpulkan bahwa variabel operating capacity tidak berpengaruh signifikan terhadap terjadinya financial distress. Dengan demikian hipotesis penelitian H01 diterima dan hipotesis penelitian Ha1 ditolak, yaitu operating capacity tidak berpengaruh signifikan terhadap terjadinya financial distress.

\section{Pengaruh sales growth terhadap financial distress}

Berdasarkan pengujian secara parsial diketahui bahwa variabel sales growth memiliki nilai koefisien sebesar -2,289 dengan nilai signifikansi sebesar 0,340 lebih besar dari tingkat signifikansi yang disyaratkan yaitu $\alpha 0,05$ (5\%). Sehingga dapat disimpulkan bahwa sales growth tidak berpengaruh signifikan terhadap terjadinya financial distress. Dengan demikian penelitian $\mathrm{H} 02$ diterima dan hipotesis $\mathrm{Ha} 2$ ditolak, yaitu sales growth tidak berpengaruh signifikan terhadap terjadinya financial distress atau semakin tinggi nilai sales growth suatu perusahaan tidak dapat mempengarui terjadinya financial distress.

\section{Pengaruh arus kas operasi terhadap financial distress}

Berdasarkan pengujian secara parsial diketahui bahwa variabel arus kas operasi yang diproksikan dengan rasio arus kas operasi terhadap utang lancar memiliki nilai koefisien sebesar 3,934 dengan nilai signifikansi sebesar 0,012 lebih kecil dari tingkat signifikansi yang disyaratkan yaitu $\alpha 0,05$. Sehingga dapat disimpulkan bahwa variabel arus ka soperasi berpengaruh signifikan terhadap financial distress. Dengan demikian hipotesis $\mathrm{H} 03$ ditolak dan hipotesis penelitian Ha3 diterima, yaitu arus kas operasi berpengaruh signifikan terhadap terjadinya financial distress, namun hasil tersebut tidak mendukung hipotesis yang dirumuskan yaitu berpengaruh secara negatif atau semakin besar nilai arus kas operasi semakin kecil kemungkinan perusahaan mengalami financial distress begitu sebalikya. Hipotesis yang dirumuskan mengalami perubahan menjadi positif.

\section{SIMPULAN}

Pada penelitian ini variabel dependen (Y) yang digunakan adalah financial distress dengan varuabel independen (X) operating capacity, sales growth dan arus kas operasi. Penelitian ini bertujuan untuk mengetahui pengaruh antara variabel independen $(\mathrm{X})$ dengan variabel dependen (Y). Hasil dari penelitian ini bahwa secara simultan operating capacity, sales growth dan arus kas operasi berpengaruh terhadap terjadinya financial distress. Sedangkan, secara parsial operating capacity dan sales growth tidak berpengaruh terhadap terjadinya financial distress. Arus kas operasi berpengaruh positif dan signifikan terhadap terjadinya financial distress. 


\section{SARAN}

Saran yang dapat diberikan oleh peneliti dari hasil penelitian yang telah dilakukan antara lain adalah untuk peneliti selanjutnya diharapkan menguji variabel lainnya yang diduga memiliki pengaruh terhadap terjadinya financial distress seperti Good Corporate Governance, rasio leverage ataupun faktor-faktor ekonomi makro yang dapat mempengaruhi seperti inflasi.

\section{DAFTAR PUSTAKA}

Halim, M. M. (2016). Analisis Laporan keuangan. UPP STIM YKPN.

Kasmir. (2017). Analisis Laporan Keuangan. Jakarta: PT. Raja Grafindo.

Gustyana, M. R. (2018). Potensi Kebangkrutan Menggunakan Model Zavgren Dan Altman Pada Subsektor Tekstil dan Garmen di BEI .

Sopian, W. P. (2017). Pengaruh Rasio Keuangan dan Ukuran Perusahaan Terhadap Financial Distress. STIE STAN-IM.

Harahap, S. S. (2010). Analisis Kritis Atas Laporan Keuangan. Rajawali Persada.

Fahmi, I. (2014). Pengantar Manajemen Keuangan. Bandung: Alfabeta.

Hery. (2015). Analisis Kinerja Manajemen. Jakarta: PT. Grafindo.

Sujarweni, V. W. (2015). Metodelogi Penelitian Bisnis Ekonomi. Yogyakarta: PUSTAKABARUPRESS.

Maryanti, E. (2016). Analisis Proditabilitas, Pertumbuhan Perusahaan, Pertumbuhan Penjualan dan Struktur Aktiba terhadap Struktur Modal pada Perusahaan Sektor Industri Barang Konsumsi yang terdaftar di Bursa Efek Indonesia. Riset Akuntansi dan Keuangan Indonesia 1(2).

Meiranto, M. A. (2014). Prediksi Financial Distress Perusahaan Manufaktur Di Indonesia.

Merkusiwati, N. L. (2015). Pengaruh Rasio Likuiditas, Leverage, Operating Capacity dan Sales Growth Terhadap Financial Distress.

Sri Yati, K. I. (2017). Analisis Penilaian Financial Distress Menggunakan Model Altman (Z-Score) Pada Perusahaan Farmasi Yang Terdaftar Di Bursa Efek Indonesia Periode 2013-2015. 5.

Ulfi Amarilla, K. N. (2017). Pengaruh Arus Kas Operasi dan Ukuran Perusahaan Terhadap Financial Distress.

Verani Carolina, E. I. (2017). Analisis Rasio Keuangan untuk Memprediksi Kondisi Financial Distress. Jurnal Akuntansi Maranatha, 9. 